\title{
Front Matter: Volume 10937
}

, "Front Matter: Volume 10937," Proc. SPIE 10937, Optical Data Science II, 1093701 (29 April 2019); doi: 10.1117/12.2531292

SPIE. Event: SPIE OPTO, 2019, San Francisco, California, United States 


\title{
PROCEEDINGS OF SPIE
}

\section{Optical Data Science II}

\author{
Bahram Jalali \\ Ken-ichi Kitayama \\ Editors
}

6 February 2019

San Francisco, California, United States

Sponsored and Published by

SPIE 
The papers in this volume were part of the technical conference cited on the cover and title page. Papers were selected and subject to review by the editors and conference program committee. Some conference presentations may not be available for publication. Additional papers and presentation recordings may be available online in the SPIE Digital Library at SPIEDigitalLibrary.org.

The papers reflect the work and thoughts of the authors and are published herein as submitted. The publisher is not responsible for the validity of the information or for any outcomes resulting from reliance thereon.

Please use the following format to cite material from these proceedings:

Author(s), "Title of Paper," in Optical Data Science II, edited by Bahram Jalali, Ken-ichi Kitayama, Proceedings of SPIE Vol. 10937 (SPIE, Bellingham, WA, 2019) Seven-digit Article CID Number.

ISSN: 0277-786X

ISSN: 1996-756X (electronic)

ISBN: 9781510625167

ISBN: 9781510625174 (electronic)

Published by

SPIE

P.O. Box 10, Bellingham, Washington 98227-0010 USA

Telephone +1 3606763290 (Pacific Time) · Fax +1 3606471445

SPIE.org

Copyright @ 2019, Society of Photo-Optical Instrumentation Engineers.

Copying of material in this book for internal or personal use, or for the internal or personal use of specific clients, beyond the fair use provisions granted by the U.S. Copyright Law is authorized by SPIE subject to payment of copying fees. The Transactional Reporting Service base fee for this volume is $\$ 18.00$ per article (or portion thereof), which should be paid directly to the Copyright Clearance Center (CCC), 222 Rosewood Drive, Danvers, MA 01923. Payment may also be made electronically through CCC Online at copyright.com. Other copying for republication, resale, advertising or promotion, or any form of systematic or multiple reproduction of any material in this book is prohibited except with permission in writing from the publisher. The CCC fee code is 0277$786 \mathrm{X} / 19 / \$ 18.00$.

Printed in the United States of America by Curran Associates, Inc., under license from SPIE.

Publication of record for individual papers is online in the SPIE Digital Library.

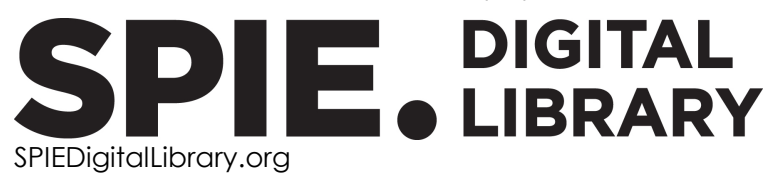

Paper Numbering: Proceedings of SPIE follow an e-First publication model. A unique citation identifier (CID) number is assigned to each article at the time of publication. Utilization of CIDs allows articles to be fully citable as soon as they are published online, and connects the same identifier to all online and print versions of the publication. SPIE uses a seven-digit CID article numbering system structured as follows:

- The first five digits correspond to the SPIE volume number.

- The last two digits indicate publication order within the volume using a Base 36 numbering system employing both numerals and letters. These two-number sets start with 00, 01, 02, 03, 04, $05,06,07,08,09,0 A, 0 B \ldots$. OZ, followed by 10-1Z, 20-2Z, etc. The CID Number appears on each page of the manuscript. 


\title{
Contents
}

\author{
$\checkmark \quad$ Authors \\ vii Conference Committee \\ ix Introduction
}

SESSION 1 EMERGING TECHNIQUES

$1093704 \quad$ Ultrafast linear array detector for real-time imaging (Invited Paper) [10937-2]

SESSION 2 KEYNOTE SESSION

$1093707 \quad$ Ultimate augmented reality displays with passive optics: fundamentals and limitations (Keynote Paper) [10937-5]

\section{SESSION $3 \quad$ AI IN COMPUTATIONAL SENSING AND IMAGING}

$10937 \mathrm{OB} \quad$ Recent results using laser speckle in multimode waveguides for random projections (Invited Paper) [10937-9]

10937 OC Waveform digitizer based lock-in amplifier using GPU digital signal processing (Invited Paper) [10937-10]

\section{SESSION 4 DEEP LEARNING MICROSCOPY}

$10937 \mathrm{OH} \quad$ New approach for luminescence sensing based on machine learning [10937-14]

1093701 Training a CNN to robustly segment the human body parts in range image sequences [10937-15]

10937 0J Fiber optical distributed acoustic sensing signal enhancements using ultrafast laser and artificial intelligence for human movement detection and pipeline monitoring [10937-16] 


\section{POSTER SESSION}

$10937 \mathrm{OL}$ Convolutional neural networks for the reconstruction of spectra in compressive sensing spectrometers [10937-20] 


\section{Authors}

Numbers in the index correspond to the last two digits of the seven-digit citation identifier (CID) article numbering system used in Proceedings of SPIE. The first five digits reflect the volume number. Base 36 numbering is employed for the last two digits and indicates the order of articles within the volume. Numbers start with $00,01,02,03,04,05,06,07,08,09,0 A, 0 B \ldots . .0 Z$, followed by 10-1Z, 20-2Z, etc.

Balzer, M. Norbert, 04

Baumgartner, Michael, $\mathrm{OH}$

Bielawski, S., 04

Boisvert, Jonathan, 01

Bründermann, E., 04

Caselle, M., 04

Castonguay, Alexandre, $\mathrm{OC}$

Chen, Kevin P., OJ

Chilingaryan, S. A., 04

Deterre, Romain, $0 \mathrm{C}$

Drouin, Marc-Antoine, $\mathrm{Ol}$

Funkner, S., 04

Godin, Guy, Ol

Heshmat, Barmak, 07

Jian, Jianan, OJ

Jiang, Desheng, OJ

Khalid, Muneeb, OC

$\mathrm{Kim}$, Cheolsun, $\mathrm{OL}$

Kopmann, A., 04

Lee, Heung-No, OL

Liu, Hu, OJ

Mao, Zhihong, OJ

Michelucci, Umberto, $\mathrm{OH}$

Müller, A. S., 04

Nasse, M., 04

Niehues, G., 04

Park, Dongju, OL

Patil, M. Mahaveer, 04

Peng, Zhaogiang, OJ

Picard, Michel, $\mathrm{Ol}$

Rota, Lorenzo, 04

Scofield, Adam C., OB

Sefler, George A., OB

Seoud, Lama, Ol

Shaw, T. Justin, OB

Tian, Moqian, 07

Valley, George C., OB

Venturini, Francesca, $\mathrm{OH}$

Wang, Mohan, OJ

Wang, W., 04

Weber, M., 04

Wei, Leihao, 07

Wen, HongQiao, OJ 
Proc. of SPIE Vol. 10937 1093701-6

Downloaded From: https://www.spiedigitallibrary.org/conference-proceedings-of-spie on 26 Apr 2023 Terms of Use: https://www.spiedigitallibrary.org/terms-of-use 


\section{Conference Committee}

Symposium Chairs

Connie J. Chang-Hasnain, University of California, Berkeley (United States)

Graham T. Reed, Optoelectronics Research Centre, University of Southampton (United Kingdom)

Symposium Co-chairs

Sailing He, KTH Royal Institute of Technology (Sweden) and Zhejiang University (China)

Yasuhiro Koike, Keio University (Japan)

Program Track Chair

David L. Andrews, University of East Anglia (United States)

Conference Chair

Bahram Jalali, University of California, Los Angeles (United States)

Conference Co-chair

Ken-ichi Kitayama, The Graduate School for the Creation of New Photonics Industries (Japan)

Conference Program Committee

Peter Bienstman, Photonics Research Group, Ghent University (Belgium)

David J. Brady, Duke Kunshan University (China)

Mark A. Foster, Johns Hopkins University (United States)

Robert Alexander Huber, Universität zu Lübeck (Germany)

Muneeb Khalid, Alazar Technologies, Inc. (Canada)

Cejo Konuparamban Lonappan, University of California, Los Angeles (United States)

Ruben S. Luís, National Institute of Information and Communications Technology (Japan)

Nguyen X. Nguyen, Cosemi Technologies, Inc. (United States)

Aydogan Ozcan, University of California, Los Angeles (United States)

YongKeun Park, KAIST (Korea, Republic of)

Andrew Rickman, Rockley Photonics (United States)

Kai Sun, Tongji University (China)

Madhuri Suthar, University of California, Los Angeles (United States) 
Zeev Zalevsky, Bar-llan University (Israel)

Lei Zhang, The Hong Kong Polytechnic University (Hong Kong, China) Darko Zibar, DTU Fotonik (Denmark)

\section{Session Chairs}

1 Emerging Techniques

Barmak Heshmat, Meta Company (United States)

2 Keynote Session

Natan Tzvi Shaked, Tel Aviv University (Israel)

3 Al in Computational Sensing and Imaging

Demetri Psaltis, Ecole Polytechnique Fédérale de Lausanne (Switzerland)

4 Deep Learning Microscopy

Madhuri Suthar, University of California, Los Angeles (United States) 


\section{Introduction}

The exponential increase in the amount of data created every day has led to a new era in data exploration and utilization. Optical sensors capture a massive amount of data and optical network transport this data across long distances. The field of biological research and healthcare has been transformed by the developments in photonics ranging from advanced imaging, tomography, and spectroscopy. Optical image sensors are able to acquire a vast amount of data at video frame rates. These trends are fueling the need and the opportunity for artificial intelligence (AI) techniques to process and extract insight from such large datasets. Integration of optical sensors with digital algorithms represents a huge near-term opportunity. At the same time, processing of data closer to the sensor, i.e. at the edge, will reduce the burden on the communication networks and alleviate bottlenecks in server-side processing. Opportunity also exists for photonic hardware accelerators that taking advantage of all-optical signal processing including spatial Fourier transformation and time stretch dispersive Fourier transformation of temporal data. Optical implementation of neural networks may offer power and speed advantages and may find utility in certain applications.

Early examples for convergence of $\mathrm{Al}$ and photonics include integration of artificial intelligence with various types of microscopy for classification of biological cells and tissue and $\mathrm{Al}$ enhancement of image resolution and denoising. Integration of deep learning with label-free time stretch microscopy has led to detection and classification of rare cancer cells in blood with high accuracy. Deep learning has been used to learn the mapping resulting from mode mixing in multimode fibers. Machine learning algorithms have shown promise in improving signal detection in optical communication and sensing. In the field of cybersecurity, optics can offer means to generate and distribute keys for encrypted communication.

The goal of this conference is to serve as a unique platform for bringing together artificial intelligence and photonics researchers from around the world to showcase the newest trends and best practices.

Bahram Jalali Ken-ichi Kitayama 
Proc. of SPIE Vol. 10937 1093701-10 Downloaded From: https://www.spiedigitallibrary.org/conference-proceedings-of-spie on 26 Apr 2023
Terms of Use: https://www.spiedigitallibrary.org/terms-of-use 